\title{
A Case Study of the Organization and Management of Bongabon Market Vendors Multi-Purpose Cooperative
}

\author{
Fhrizz S. De Jesus, Cleah F. Dela Cruz \\ Nueva Ecija University of Science and Technology, Cabanatuan, Philippines \\ Email: fhrizzdejesus01@gmail.com
}

How to cite this paper: De Jesus, F.S. and Cruz, C.F.D. (2021) A Case Study of the Organization and Management of Bongabon Market Vendors Multi-Purpose Cooperative. Open Access Library Journal, 8: e7204. https://doi.org/10.4236/oalib.1107204

Received: February 1, 2021

Accepted: March 20, 2021

Published: March 23, 2021

Copyright $\odot 2021$ by author(s) and Open Access Library Inc.

This work is licensed under the Creative Commons Attribution International License (CC BY 4.0).

http://creativecommons.org/licenses/by/4.0/

(c) (i) Open Access

\begin{abstract}
This study described the Case of the Organization and Management of Bongabon Market Vendors Multi-Purpose Cooperative (BMVMPC). Specifically, it looked into the problems encountered of the Bongabon Market Vendor and analyzed how four Functions of Management contributes the problem of the Cooperative Market Vendor. This study used the descriptive-evaluative method and total enumeration for its sampling procedure. As to its findings, to ensure the respondents' profitability and longevity, they "always" practice Four Functions of Management in the Bongabon Market Vendor MultiPurpose Cooperative. Planning ranked number one among the four functions of management wherein Controlling ranked last. Based on the result, Planning ranked as number 1 in the assessment of the respondents based on Four Functions of Management. This means that a Cooperative business performs best if the connectivity of all the variables of a business works successfully and efficiently against its members. This study also revealed different problems of the respondents in different aspects of its operation. More so, based on the problems encountered by the respondents, the researchers categorized all the problems and based on the results, they found out that the number one problem of the Cooperative Market Vendor was Time Management.
\end{abstract}

\section{Subject Areas}

Business and Economics, Education, Social Science

\section{Keywords}

Functions of Management, Cooperative, Vendors 


\section{Introduction}

Cooperative, as a form of organization, has been promoted and created in many [developing] countries to advocate and address issues such as unemployment. It creates income generating activities and builds societies. Unlike ordinary corporations, members of a cooperative are involved in the decision-making process and are the primary users of its own products or services. It is ideally designed to be an easy method of development in these countries. Thus, all over the world, millions of people have chosen the cooperative model enterprise as a way of empowering them to reach personal and community development goals of creating and maintaining employment as well as producing and supplying products and services to their own members and communities.

Bongabon Market Vendors Multi-Purpose Cooperative (BMVMPC) registered under the Cooperative Development Authority with a registration number: 9052-03003990 in the Province of Nueva Ecija Region 3, is a cooperative that generates some activities and programs that helps their members to sell their products by providing them some helpful techniques and strategies that would help them to grow their profits. This cooperative provides help to its members not only in their financial capabilities but as well as to other factors of their lives.

The successful cooperatives have a well-defined operation and management system. If this aspect of business does not work well, then the aim of the cooperative will not be achieved. A key challenge within co-operatives is a lack of transparency between the governing board and the general members [1]. This issue is under the Organization and Management aspect of business operation [2]. The primary role of the managers in business is to supervise other people's performance. Most management activities fall into the following categories such as Planning, Organizing, Controlling, and Leading not only the Human Capital of the industry but also settings its vision, mission, and goals concerning its interactions to its stakeholders. If these factors under the organization and management aspect of the business will become an issue, hence, it will decrease the over-all performance of the business.

With the above statements, the researchers believe that the performance of BMVMPC will be enhanced if their organization and management aspect will be assessed and determine the problems encountered by their members.

This research assesses the demographic profile of the Market Vendor in Bongabon and the four functions of management. The researcher believes that by using the four functions of management in this study, it might provide recalibration of the management plan that might contribute to the sustainability and profitability of the cooperative.

\section{Conceptual/Theoretical Framework}

This study was based on the four functions of management and the profile of the respondents. 
The researcher used these variables to determine, describe, and assess the problems encountered of the Bongabon Market Vendor using the four functions of management.

The demographic profile was used to describe the sex, years of membership and the share capital of the members of the cooperative. These are the demographic information that provides data regarding research participants and is necessary for the determination of whether the individuals in a particular study.

Under the demographic profile, basically, it determined the sex to know if men have different mindset by dealing a product in the market than the women. And by knowing who are more interested by being a vendor in the market whether it can be a man or a woman.

Years of membership represent that you are part of the organization and if you can sustain their performance for a longer period of time.

Lastly, the Shared Capital maybe altered or increased, and it represents the money of a company by issuing common or preferred stock. The amount of shared capital or equity financing a company has can change over time with additional public offerings.

Four functions of management can be the most effective tool in identifying the problems encountered by Bongabon marketing Cooperative members, and it helps the cooperative to be more productive and effective.

The first function of management is the planning, it gives a sense of direction to the entire team of the organization [3]. It first requires managers to be aware of challenges facing their businesses, and it then requires managers to forecast business and economic conditions. At the planning stage, they need to set goals to identify and consider their benefits in the cooperative. And it uses the cooperative's strengths to put it in the best possible position while change is occurring. It also devises steps to minimize the cooperative's weaknesses, or even better, devises steps that turn its weaknesses into strengths.

Organizing is the second function of management and it represents the establishments of effective authority relationships among selected work, persons and workplaces in order for the group to work together efficiently [4]. It helps in defining the roles of every person and therefore defines the hierarchy in the organization in a better manner. Such systematic arrangements lead to better coordination among the teams and departments therefore helping in the overall development of organization and its goals.

Leading is another function of management and it means having a vision and sharing it with others. They are responsible for defining operational or management level objectives, goals, and policies to achieve the defined goals. And they need to encourage their team to know what they can do to help the cooperative grows.

Controlling is the last function of management that involves ensuring performance does not deviate from standards. Controlling consists of three steps, which include establishing performance standards, comparing actual perfor- 
mance, and taking corrective action when necessary. And it helps to identify the error and deviation from standards so that corrective actions can be taken to achieve goals and to ensure that the specific functions are performed according to established standards.

Figure 1 shows the research paradigm of the study. The researchers used the input, process output format.

For the input phase, the demographic profile of the respondents such as sex, years of membership and share capital were used.

In the process phase, the functions of management such as planning, organizing, leading, and controlling were the variables used to evaluate the respondents.

Finally, for the output phase, identification of the problems encountered of the respondents in terms of the organization and management aspect of business.

\section{Methodology}

The researchers used a mixed method of research in the evaluation of the topic. They applied both the quantitative and qualitative types of research.

Quantitative research was appropriate in this study as it required computation of frequencies and percentages to evaluate variables of this study [5]. A quantitative research involves the use of computational, statistical, and mathematical tools to derive results. It is conclusive in its purpose as it tries to quantify the problem and comprehend how prevalent it is by looking for projectable outcomes for a larger population.

The researchers also used the qualitative method of research in this study for it required observation of the existing operations of the Bongabon Marketing Cooperative as well as an interview with the respondents regarding the problems they encountered in terms of the organization and management aspect of business operation [6]. A qualitative method is used to answer questions about experience, meaning and perspective, most often from the standpoint of the participant. These data are generally not amenable to counting or measuring.

Descriptive-evaluative method of research includes interviews and mailed questionnaires [7]. Often, it comprises a group that is preselected without any base group to compare the result.
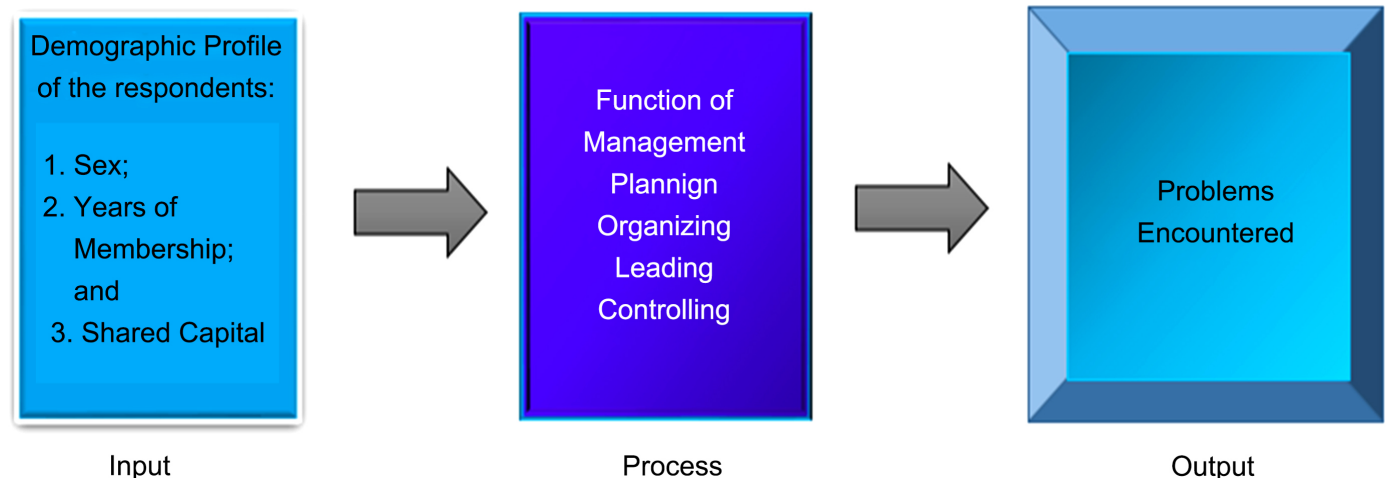

Process

Output

Figure 1. Research paradigm. 
This study was conducted in municipality of Bongabon in Nueva Ecija province. The Bongabon Market Vendors Multi-Purpose Cooperative is located in this municipality.

This study used total enumeration as a method of gathering data [8]. Total enumeration is a study of every unit, everyone or everything, in a given population. It is also known as complete enumeration, which means a complete count. The researcher used this sampling method as the total number of respondents was feasible for the researcher to get an accurate data and information. The total respondents for this study are 60, who are members of the BMVMPC. These were the chosen respondents of the study because they were the ones who were experiencing the leadership and management style of the cooperative, also, their honest opinions about their problems encountered were also discovered in this study.

In this study, the questionnaire instrument was utilized to collect the information needed. The research instrument helped the researchers to keep track of the evaluation in order to validate the information gathered. Furthermore, the researchers also had conducted series of interviews to validate the answers of the respondents. The researchers establish face validity and conducted a pilot test. The result of the pilot test was encoded in a spreadsheet and computed thru Principal Component Analysis. After the result was computed, immediate action was done in the revision of instrument. The reliability coefficient of the instrument has a score of 0.860 , which means that the instrument has a good internal consistency. This reliability test was conducted with another group of respondents. The validity of the research instrument was established by presenting the developed research instrument for the comments of experts who all together rated the instrument with 4.80 weighted mean with a verbal interpretation of "very good".

The researchers use developed questionnaire, and conduct interview as their research instrument. The research instrument was properly validated, corrections and suggestions by experts were also incorporated in final draft. Interviews were done with every respondent in order to check the reliability and validity of the questionnaire. The questionnaire has 3 parts. Part 1 contained the demographic profile of the respondents such as composed of Sex, Years of membership and Shared Capital. Part 2 contained the assessment of the functions of management under the organization and management aspect of the cooperative. This part of the instrument was formulated in the modified 4-point Likert-scale (Always (4); Sometimes (3); Seldom (2); and Never (1). Subjects were instructed to rate the statements and answer the question. Lastly, Part 3 of the questionnaire comprised of the problems encountered by the respondents under the organization and management aspect of the cooperative. This part was made up of an open-ended question. The respondents were asked to write their honest opinions regarding the questions being asked.

Also, to avoid personal bias, member checks were utilized during and after 
interviews, thus increasing credibility, validity, and transferability of the findings [9].

The data collected from the locale were encoded, tallied and analyzed using the following statistical tools were used. Data presentation of the given scale was used to interpret the results of the information gathered.

To determine the respondents' degree of perception, the weighted mean was computed using the following formula: Weighted mean $(\Sigma W M)$ is equal to total weighted frequency ( $\Sigma \mathrm{WF}$ ) divided by the total number of cases $(\mathrm{F})$.

The percentage frequency distribution was computed using the formula: frequency (F) divided by the sample (N) and multiply by one hundred (100). The researchers used ranking to compare items to each other by placing them in order of preferences.

\section{Results and Discussions}

The following (Table 1) are the results and discussions about the demographic profile of the respondents.

The result indicates that most number of members of the cooperative are females. They are more interested in terms of selling a product and they are capable in managing business. In addition, they also tend to make strong selling points and uncover important information while listening to customers, which allows them to be more persuasive and persistent.

Respondents revealed that the women members of the cooperative are more likely to engage in the marketing of the cooperative while the men focus on other aspects of the cooperative. As added, in terms of the leadership skills, men are more qualified because of their strong leadership style.

Majority of the years of membership of the cooperative are 5 - $\mathbf{6}$ years with $33 \%$ of the respondents (Table 2). By joining their organization, they are demonstrating their commitment and understanding of the importance of being a vendor in the community. The respondents said the most important advantage for the members is the presence of the co-op itself. And that's why they join the cooperative because they want to use its services and connections. In addition, members receive benefits from being a part of the community, supporting the goal of the co-op as well as the community it serves.

The co-op's purpose is to meet member needs, and members need to understand that fulfilling that purpose takes capital [10]. Therefore, those members who stay for a long time receive the full benefits of the cooperative.

Table 1. Sex.

\begin{tabular}{ccc}
\hline Sex & Frequency & Percentage \\
\hline Male & 24 & $40 \%$ \\
Female & 36 & $60 \%$ \\
Total & 60 & $100 \%$ \\
\hline
\end{tabular}


Based on the survey, $44 \%$ of the members of the cooperative have a shared capital of $\mathbf{1 1 0 0}-\mathbf{2 0 0 0}$ (Table 3). The result implied that since the members are vendors in the market, their shared capitals were only based on the excess money they have. On the other hand, though their shared capital is small, they are still trying to add some capital to help their cooperative in the accomplishment of its goals.

When members join an existing cooperative, they may be required to invest a nominal amount and then agree to invest over time by allowing the cooperative to keep or retain a portion of each year's cooperative earnings as equity capital [11]. The owners or the members have to be ultimate providers of the funds that are needed, over and above what gets generated by the normal flow of the business operations.

The next part of the results and discussion presents the functions of management of the respondents.

The finding (Table 4) shows that the respondents conduct an observation in the market before doing anything. According to the respondents, it is important to know the environmental condition before making a decision because their decision matters on the goals of the cooperative and because of that it helps them to provide the best courses of actions for achieving objectives.

In relation with the above findings, the scholars argue that the decision-making process is influenced by the environment, and individuals tend to have an adaptive characteristic [12]. Hence, the respondents make their planning decision based on the result of the observation they have conducted.

Table 2. Years of membership.

\begin{tabular}{ccc}
\hline Years of Membership & Frequency & Percentage \\
\hline $1-2$ years & 10 & $17 \%$ \\
$3-4$ years & 14 & $23 \%$ \\
$5-6$ years & 20 & $33 \%$ \\
7 and above & 16 & $27 \%$ \\
Total & 60 & $100 \%$ \\
\hline
\end{tabular}

Table 3. Shared capital.

\begin{tabular}{ccc}
\hline Shared capital & Frequency & Percentage \\
\hline P $100-500$ & 4 & $7 \%$ \\
P $600-1000$ & 20 & $33 \%$ \\
P $1100-2000$ & 26 & $44 \%$ \\
P $2100-3000$ & 2 & $3 \%$ \\
P $3100-4000$ & 2 & $3 \%$ \\
P 4100 - 5000 & 2 & $3 \%$ \\
P 5100 and Above & 4 & $7 \%$ \\
Total & 60 & $100 \%$
\end{tabular}


Table 4. Planning.

\begin{tabular}{|c|c|c|c|c|}
\hline Planning & W.M & VI & Rank & VD \\
\hline $\begin{array}{l}\text { 1) Cooperative analyzes first the } \\
\text { environmental condition before } \\
\text { making a decision. }\end{array}$ & 4.00 & ALWAYS & 1 & $\begin{array}{l}\text { The statement was } \\
\text { practiced all the time }\end{array}$ \\
\hline $\begin{array}{l}\text { 2) Cooperative knows how to } \\
\text { forecast future conditions. }\end{array}$ & 3.93 & ALWAYS & 4 & $\begin{array}{l}\text { The statement was } \\
\text { practiced all the time }\end{array}$ \\
\hline $\begin{array}{l}\text { 3) Provides courses of action for } \\
\text { achieving objectives. }\end{array}$ & 3.98 & ALWAYS & 2 & $\begin{array}{l}\text { The statement was } \\
\text { practiced all the time }\end{array}$ \\
\hline $\begin{array}{l}\text { 4) Deals customers and } \\
\text { competitors. }\end{array}$ & 3.80 & ALWAYS & 6 & $\begin{array}{l}\text { The statement was } \\
\text { practiced all the time }\end{array}$ \\
\hline $\begin{array}{l}\text { 5) Provides alternative } \\
\text { solutions/actions. }\end{array}$ & 3.88 & ALWAYS & 5 & $\begin{array}{l}\text { The statement was } \\
\text { practiced all the time }\end{array}$ \\
\hline $\begin{array}{l}\text { 6) Ensures to implement plans } \\
\text { effectively. }\end{array}$ & 3.95 & ALWAYS & 3 & $\begin{array}{l}\text { The statement was } \\
\text { practiced all the time }\end{array}$ \\
\hline TWM & 3.92 & ALWAYS & & $\begin{array}{l}\text { The statement was } \\
\text { practiced all the time }\end{array}$ \\
\hline
\end{tabular}

Other results under planning implied that their courses of actions were based on their objectives. It shows that the plan and the objectives of the respondents were aligned to one another. It is important that these two are aligned so that the implementation of the plan will be ensured. In line with this, the respondents can prepare their future possible interventions for the possible problems that may occur. Nevertheless, by doing the said actions, it will result in providing the best customers service and may result in an increase of their business performance.

The above findings show that the cooperative defines inter-relationship among vendors for productive cooperation ranked as number one with a weighted mean of 4.00 and verbally interpreted as always (Table 5). This finding implies that working together achieves a common goal. In the cooperative, this means that a healthy environment in which employees work side by side can achieve both personal and organizational goals.

The respondents stated that it is important to have a positive interaction with the members of the cooperative because it will make the business stay in the competition. As added, collaboration skills enable them to successfully work toward a common goal with others. They include cooperating clearly, actively listening to others, taking responsibility for errors, and respecting the multiplicity of their members.

Collaboration is when a group of people come together and contribute their expertise for the benefit of a shared objective, project, or mission [13]. In other words, collaboration is the progression of team work. But it's also a cultured skill. Collaboration with others will significantly impact the outcome of the group project. 
Table 5. Organizing.

\begin{tabular}{|c|c|c|c|c|}
\hline Organizing & W.M & VI & Rank & VD \\
\hline $\begin{array}{l}\text { 1) Creates organizational structure } \\
\text { with suitable personnel. }\end{array}$ & 3.97 & ALWAYS & 2.5 & $\begin{array}{l}\text { The statement was } \\
\text { practiced all the time }\end{array}$ \\
\hline 2) Sets vendors where they best fit. & 3.87 & ALWAYS & 7 & $\begin{array}{l}\text { The statement was } \\
\text { practiced all the time }\end{array}$ \\
\hline $\begin{array}{l}\text { 3) Develops effective and transparent } \\
\text { job practices. }\end{array}$ & 3.93 & ALWAYS & 5 & $\begin{array}{l}\text { The statement was } \\
\text { practiced all the time }\end{array}$ \\
\hline $\begin{array}{l}\text { 4) Vendors work together to fulfill } \\
\text { certain objectives or goals. }\end{array}$ & 3.93 & ALWAYS & 5 & $\begin{array}{l}\text { The statement was } \\
\text { practiced all the time }\end{array}$ \\
\hline 5) Enable vendors to work effectively. & 3.97 & ALWAYS & 2.5 & $\begin{array}{l}\text { The statement was } \\
\text { practiced all the time }\end{array}$ \\
\hline $\begin{array}{l}\text { 6) Designs specific roles to eliminate } \\
\text { ambiguity. }\end{array}$ & 3.93 & ALWAYS & 5 & $\begin{array}{l}\text { The statement was } \\
\text { practiced all the time }\end{array}$ \\
\hline $\begin{array}{l}\text { 7) Defines inter-relationship among } \\
\text { vendors for productive cooperation. }\end{array}$ & 4.00 & ALWAYS & 1 & $\begin{array}{l}\text { The statement was } \\
\text { practiced all the time }\end{array}$ \\
\hline TWM & 3.94 & ALWAYS & & $\begin{array}{l}\text { The statement was } \\
\text { practiced all the time }\end{array}$ \\
\hline
\end{tabular}

Other results under organizing show that establishing roles to accomplish the goal of the cooperative is one of the considerations. If the cooperative has no clear persons to do a specific task, the accomplishment of the goal will be in delay or worse will not be achieved. According to the respondents, each of the members has its own role in accomplishing the cooperative's goal. They are all working together towards it.

Table 6 shows that cooperative values their members. It implied that the cooperative provides the outmost support and motivation that they can give to their members. On the other hand, the cooperative receives the same treatment from their members which causes a positive impact on their coop's performance.

Most of the respondents said, motivation is a very strong tool they can use to get further in life and to achieve their goals. Moreover, vendors are being valued by the cooperative because they are bidding to provide services to many agencies, they can afford to offer steeper discounts to the end users of a contract. Also, according to the respondents, it is important to listen and understand the vendors concerns to prevent miscommunications because effective communication allows team members to understand their roles and the roles of everyone else on the team. It also gives room for understanding among the vendors for their different concerns.

In order for a cooperative learning group to grow, individuals within the group need to execute leadership abilities. Without this, the group cannot move forward without a teacher [14]. A cooperative practice is an action that supports, complements, or carries out a principle. The practice is particularly important for a cooperative to achieve success. 
The result (Table 7) shows that the cooperative has a good system in implementing its plan. The implementation includes the members, and the resources of the cooperative, these 2 have their own means of helping the operation. According to the respondents, there is no perfect organization at all, but their cooperative tries to check the errors and provide helpful actions immediately.

Controlling or Control management is important in an organization because it helps to check errors and implement corrective action, minimizing deviation from standards, and keeps your project management on track [15].

Table 6. Leading.

\begin{tabular}{|c|c|c|c|c|}
\hline LEADING & W.M & VI & Rank & VD \\
\hline $\begin{array}{l}\text { 1) Vendors are being influenced and } \\
\text { motivated to achieve specific goals }\end{array}$ & 3.88 & ALWAYS & 3 & $\begin{array}{l}\text { The statement was } \\
\text { practiced all the time }\end{array}$ \\
\hline $\begin{array}{l}\text { 2) Cooperative provides good } \\
\text { relationship towards vendors }\end{array}$ & 3.87 & ALWAYS & 4 & $\begin{array}{l}\text { The statement was } \\
\text { practiced all the time }\end{array}$ \\
\hline $\begin{array}{l}\text { 3) Cooperative provides an environment } \\
\text { wherein vendors can focus and moves } \\
\text { confidently }\end{array}$ & 3.80 & ALWAYS & 5 & $\begin{array}{l}\text { The statement was } \\
\text { practiced all the time }\end{array}$ \\
\hline $\begin{array}{l}\text { 4) Vendors are being valued by the } \\
\text { cooperative }\end{array}$ & 4 & ALWAYS & 1.5 & $\begin{array}{l}\text { The statement was } \\
\text { practiced all the time }\end{array}$ \\
\hline $\begin{array}{l}\text { 5) Cooperative listens and understands } \\
\text { the vendors concerns }\end{array}$ & 4 & ALWAYS & 1.5 & $\begin{array}{l}\text { The statement was } \\
\text { practiced all the time }\end{array}$ \\
\hline TWM & 3.93 & ALWAYS & & $\begin{array}{l}\text { The statement was } \\
\text { practiced all the time }\end{array}$ \\
\hline
\end{tabular}

Table 7. Controlling.

\begin{tabular}{|c|c|c|c|c|}
\hline CONTROLLING & W.M & VI & Percentage & VD \\
\hline $\begin{array}{l}\text { 1) Cooperative ensures that the resources } \\
\text { are being used effectively and efficiently } \\
\text { for the achievement of goals }\end{array}$ & 4 & ALWAYS & 1.5 & $\begin{array}{l}\text { The statement was } \\
\text { practiced all the time }\end{array}$ \\
\hline $\begin{array}{l}\text { 2) Provides good control system among } \\
\text { vendors }\end{array}$ & 4 & ALWAYS & 1.5 & $\begin{array}{l}\text { The statement was } \\
\text { practiced all the time }\end{array}$ \\
\hline $\begin{array}{l}\text { 3) Creates an atmosphere of order and } \\
\text { discipline among the market vendors }\end{array}$ & 3.87 & ALWAYS & 4 & $\begin{array}{l}\text { The statement was } \\
\text { practiced all the time }\end{array}$ \\
\hline $\begin{array}{l}\text { 4) Observe progress towards the specific } \\
\text { goals }\end{array}$ & 3.8 & ALWAYS & 5 & $\begin{array}{l}\text { The statement was } \\
\text { practiced all the time }\end{array}$ \\
\hline $\begin{array}{l}\text { 5) Plans made by the cooperative are } \\
\text { properly executed }\end{array}$ & 3.93 & ALWAYS & 3 & $\begin{array}{l}\text { The statement was } \\
\text { practiced all the time }\end{array}$ \\
\hline TWM & 3.92 & ALWAYS & & $\begin{array}{l}\text { The statement was } \\
\text { practiced all the time }\end{array}$ \\
\hline
\end{tabular}


Other results under controlling show that the communication system of the cooperative works well. A good communication system leads the cooperative in solving the gaps and errors that a business will encounter in the future. It should be integrated in the controlling system of the cooperative so that it will prevent the cooperative from any negative business activities.

The next part of the results and discussion is about the problems encountered of the respondents in terms of the organization and management aspect.

Result (Table 8) shows that the difficulty in unification in multiple personalities is the top problem of the respondents. Basically, the respondents are vendors who are members of the cooperative. These persons have no formal training or background about proper way of interaction among members which causes clash of personalities. Based on the interviews conducted, the members' personality varies broadly, and the multiplicity of backgrounds, opinions, views, and experiences can be the root of challenges for the teams. This creates a distinctive set of potential issues and opportunities.

Each member or worker has an independent entity, so all companies need to address the idea of individualism in the workplace in order to remain well-organized and competitive. This should be addressed by the owner or the management [16]. Personality types are useful in recognizing how to lead, influence, communicate, collaborate, negotiate business, and manage stress. There are many means by which understanding personality type can be applied in the workplace. It can help with one's leadership style to decide conflicts more effectively, to communicate more effectively, to recognize how others make decisions, to coach others, to improve sales skills, and to retain key staff.

In line with the above discussion, skepticism is also a problem in this cooperative. Since majority of the respondents have no formal education, they do not have knowledge on how they will build confidence in the things they have done. It affects their decision-making skills which will be needed by the cooperative.

Self-doubt is a natural part of human experience [17]. Everyone has moments in which they are not certain of themselves, and for some these moments pervade into their psyche until it becomes a lifestyle [17]. Although it is detrimental to live with complete certitude in what you do, it is equally negative to lose all confidence in your capabilities. With practice and dedication, positive results will occur in the right time.

Table 8. Problems encountered in the organization and management aspect of the respondents.

\begin{tabular}{ccc}
\hline Problems & Frequency & Percentage \\
\hline Difficulty unification in multiple personalities & 35 & $58 \%$ \\
Difficulty in handling Time management & 10 & $17 \%$ \\
Pressure to perform & 5 & $8 \%$ \\
Skepticism (self-doubt to do one thing) & 10 & $17 \%$ \\
\hline
\end{tabular}


Also, another result of the study, Difficulty in handling Time management, pointed the fact that since majority of the respondents are vendors, it is hard for them to handle their time in attending cooperative meetings and business transactions because they were the only one who handles their stores in the market. In line with the organization and management aspect of the business, this problem causes delay in the transactions because of time misconception, since the decisions of the cooperative come from its members, this causes postponement of the overall and final confirmation of the agenda and other activities.

One reason that time management is difficult is due to the planning falla$c y$-something that occurs when people underestimate how long it will take to finish a task, even if they have done the task before [18]. Not only does this outcome in there not being enough time to complete the work, but people then later incline to misjudge how much time they actually spent working on the cooperative task.

\section{Conclusions and Recommendations}

Based on the result of the study, the Bongabon Market Vendors Multi-Purpose Cooperative has majority of female members who are almost 5-year members of the cooperative with almost 1000 to 2000 pesos shared capital. It shows that the cooperative was already established and they are progressively growing because of their members.

Also, the cooperative has a management system that provides utmost support to their members. Though the management team of the cooperative sets a well define system, there are other external factors that they cannot control especially those involving the unforeseen circumstances of the members.

Under the problems encountered of the respondents, it shows that the problems were coming from their own individuality which may cause the delay and other negative results of the operation of the cooperative, hence, the management of the cooperative needs to address these problems.

In line with the above discussions, it is recommended that the cooperative should strengthen the functions of their management by reinforcing their best practices and addressing their worse one for them to progressively grow. It will be the asset of the cooperative in handling their members that will result in the increase of productivity of the members as well as the cooperative.

Another recommendation for the cooperative is to provide trainings and other activities that will address the individual problems of the members, since the problems are coming personally. These can be in a form of trainings such as personality development, basic communication, a team building activity, or simple meeting.

Next recommendation is for the members, it is recommended that problems and issues should be reported to the management of the cooperative so that it will be professionally addressed.

Lastly, for the researchers and future researchers, this study could serve as a 
basis for further cooperative and business-related researches and development of extension programs such as providing technical expertise in the field of business.

\section{Conflicts of Interests}

The authors declare no conflict of interest regarding the publication of this paper.

\section{References}

[1] EcoVentures International. Co-Operative Challenges.

http://globalcooperativedevelopmentlearning.weebly.com/co-operative-challenges.h $\underline{\mathrm{tml}}$

[2] Lumen. Introduction to Business.

https://courses.lumenlearning.com/wmopen-introbusiness/chapter/functional-areas -of-business2/\#: : :text=The\%20primary\%20role\%20of\%20managers,to\%20supervise \%20other\%20people's\%20performance.\&text=Planning\%3A\%20Managers\%20plan \%20by\%20setting,to\%20execute\%20against\%20those\%20goals

[3] Norman, L. (2019) What Are the Four Basic Functions That Make Up the Management Process?

https://smallbusiness.chron.com/four-basic-functions-make-up-management-proce ss-23852.html

[4] Wikipedia. Organizing (Management). https://en.wikipedia.org/wiki/Organizing_(management)

[5] SIS International Research (2015) What Is Quantitative Research? https://www.sisinternational.com/what-is-quantitative-research/\#: :text=Quantitati ve\%20Research\%20involves\%20the\%20use,results\%20to\%20a\%20larger\%20populat ion

[6] Hammarberg, K., Kirkman, M. and de Lacey, S. (2016) Qualitative Research Methods: When to Use Them and How to Judge Them. Human Reproduction, 31, 498-501. https://doi.org/10.1093/humrep/dev334

[7] Cliff, H. (2019) What Is Descriptive Evaluative Research? https://www.quora.com/What-is-descriptive-evaluative-research

[8] Australian Bureau of Statistics (2013) Statistical Language-Census and Sample. https://www.abs.gov.au/websitedbs/D3310114.nsf/Home/Statistical+Language+-+ce nsus+and+sample

[9] Lincoln, Y.S. and Guba, E.G. (1985) Naturalistic Inquiry. Sage Publications, Inc., Newbury Park.

[10] Scholl, M. (2008) Membership Is Ownership: The Cooperative Advantage. https://www.grocer.coop/articles/membership-ownership-cooperative-advantage\#: ح:text=The\%20owners\%20provide\%20tangible\%20support,want $\% 20$ to\%20use $\% 20$ it $\underline{\mathrm{s} \% 20 \mathrm{services}}$

[11] Peterson, C. (2019) Why Cooperatives Need Money and Why Members Need to Invest Money.

https://cooperatives.extension.org/why-cooperatives-need-money-and-why-membe rs-need-to-invest-money

[12] Dietrich, C. (2010) Decision Making: Factors That Influence Decision Making, Heuristics Used, and Decision Outcomes. Inquiries Journal, 2, p. 3.

http://www.inquiriesjournal.com/articles/180/2/decision-making-factors-that-influe nce-decision-making-heuristics-used-and-decision-outcomes 
[13] Moseley, C. (2019) 7 Reasons Why Collaboration Is Important. https://blog.jostle.me/blog/why-collaboration-is-important

[14] United States Department of Agriculture (2011) Understanding Cooperatives: Cooperative Business Principles, Cooperative Information Report 45, Section 2. https://www.rd.usda.gov/files/CIR45_2.pdf

[15] Workfront (2019) What Is Control Management and Why Is It Essential? https://www.workfront.com/blog/what-control-management-and-why-it-essential

[16] Mosley, L. (2016) The Importance of Understanding Personality Type in the Workplace.

https://www.linkedin.com/pulse/importance-understanding-personality-type-work place-lauren-copeland

[17] Brown, J. (2012) 8 Great Ways to Demolish Your Skepticism. https://addicted2success.com/success-advice/8-great-ways-to-demolish-your-skepti cism-build-your-confidence

[18] Harman, J.J. (2014) Time Management for Students: A Psychological Explanation of Why We Struggle.

http://blog.online.colostate.edu/blog/online-education/time-management-for-stude nts-a-psychological-explanation-of-why-we-struggle 